УЧЕТ ОСОБЕННОСТЕЙ ИЗМЕНЕНИЯ СВОЙСТВ МАТЕРИАЛА В ТЕХНОЛОГИИ КРЕМНИЕВЫХ НАНОСТРУКТУР

\title{
ACCOUNTING OF FEATURES OF CHANGING OF MATERIAL PROPERTIES IN TECHNOLOGY OF SILICON NANOSTRUCTURES
}

\author{
УДК 54-1, ВАК 05.27.01, DOI: 10.22184/1993-8578.2017.75.4.84.103
}

\author{
Н.Герасименко ${ }^{1,2}$, А.Вомоховский', 3, О.Запорожан1 / rmta@тіее.ги \\ N.Gerasimenko ${ }^{1,2}$, A.Volokhovsky', 3, O.Zaporozhan?
}

\begin{abstract}
Рассматриваются особенности изменения физических свойств элементов структуры при их уменьшении до наноразмеров и перспективы использования этих эффектов в технологиях микроэлектроники.

The features of change of physical properties of the structure elements when reducing their size to nanoscale and the prospects for using these effects in microelectronics technology are discussed.
\end{abstract}

тавшая модной приставка "нано" нередко имеет неоднозначный смысл в статьях, диссертациях и другой научной литературе. До сих пор многие специалисты полагают, что ее следует употреблять, когда речь идет об установленном размерном параметре 100 нм и менее. На наш взгляд, это определение можно считать чисто историческим, а его научный смысл определяется существованием размерного порога, связанного с определенными физическими, химическими и другими параметрами. Например, при обсуждении электрофизических и оптических характеристик полупроводниковых материалов порог перехода к "нано" справедливо связывать с достижением, по крайней мере, одним из размерных параметров длины волны электрона (длины волны де Бройля). Для механических характеристик в качестве размерного порога используют эмпирический параметр, который для металлов и полупроводников составляет около 30 нм. Этот параметр можно связать также с изменением определенных физических величин, обусловленных близостью поверхности и т.д.
Определение явления наноразмерности затруднено появлением специфических свойств материалов, что представляет большую проблему как в изготовлении, так и в экспериментальном исследовании их свойств. Например, применяемый в твердотельной электронике монокристаллический кремний трудно получить в порошкообразном состоянии, когда можно говорить о его наносвойствах, поскольку после прохождения размерного порога нанозерна слипаются и интенсивно окисляются. В комнатных условиях последнее может приводить к взрыву.

Информация о фундаментальных свойствах новых действительно наноразмерных материалов в ряде случаев до сих пор является фрагментарной и противоречивой, затрудняя развитие реальной технологии, в частности, твердотельной наноэлектроники.

Развитие нового научного направления связано с появлением новых областей в научно-технической терминологии. Например, для термина "наноиндустрия" потребовалось специальное разъяснение в литературе [1]. С другой стороны, 
употребляемые, казалось бы, понятные термины иногда могут вводить в заблуждение. Например, часто путаются и неправильно употребляются термины "нанопровода" и "нанопроволоки".

Разумеется, новое направление требует подготовки специалистов для исследований, образования и технологий с учетом сверхбыстрого развития научных основ лабораторных и технологических подходов [2].

Особую важность новое научно-техническое направление приобретает, на наш взгляд, при переходе к промышленному освоению научных результатов, представлений, новых возможностей и технологий. Возникающие при этом трудности заставляют искать принципиально новые подходы к исследованиям, созданию технологических основ, конструированию и производству новых материалов, технологических сред и оборудования. При этом существующие технологические возможности требуют либо чрезмерных затрат, либо новых путей, а иногда и кардинальных изменений. И даже известные и достаточно хорошо освоенные промышленностью технологические средства при создании наноразмерных объектов в электронике проявляют как новые возможности, так и обуславливают новые трудности, требуя постоянного внимания со стороны исследователей и выдвигая новые принципы взаимодействия ученых и инженеров, которые можно объединить понятием "научное сопровождение технологии". Имеется ввиду постоянный процесс, а не фрагментарные контакты.
В связи с представленными выше соображениями обратим внимание на две характерные ситуации. Первая связана с проблемами применения фотолитографии в области сверхмалых размеров, где оптические приборы обретают новые конструктивные особенности в связи с продвижением в дальнюю часть УФ-диапазона, что приводит к резкому удорожанию оборудования. В последующих материалах мы расскажем о разработан ных в нашей стране и предложенных для освоения промышленностью подходах, основанных на использовании фокусированных рентгеновских пучков. Эта возможность уже обсуждалась на предприятии ПАО "Микрон" и может стать весьма перспективной.

Другой пример касается применения в промышленности метода и оборудования для ионной имплантации, и синтеза. Эта широко распространенная технология практически не используется для создания наноразмерных (квантово-размерных) структур для получения принципиально новых приборов и ИС, сочетающих возможности интегральной электроники и фотоники. В международной литературе можно встретить достаточно много материалов по этому направлению, однако квантово-размерные излучающие структуры на основе системы "германий - кремний" в подавляющем большинстве случаев изготавливаются с помощью молекулярно-лучевой эпитаксии. Первые и пока единственные работы по использованию в этих целях ионной имплантации [3, 4] показали, что подготовка ионного синтеза $\mathrm{Si}-\mathrm{Ge}$
$\mathbf{F}$ ashionable prefix "nano" often has an ambiguous meaning in the articles, theses and other scientific literature. Until now, many experts believe that it should be used when talking about the size parameter of $100 \mathrm{~nm}$ or less. In our view, this definition can be regarded as purely historical, and its scientific meaning is determined by the existence of a size threshold associated with the defined physical, chemical, and other parameters. For example, in discuss ing electrophysical and optical characteristics of semiconductors, the threshold of transition to the "nano" should be linked to the achievement of at least by one of the dimensional parameters of the wavelength of an electron (de Broglie wavelength). For mechanical characteristics as a size threshold the empirical parameter, which for metals and semiconductors is about $30 \mathrm{~nm}$, is used. This parameter can be linked also with changes in certain physical quantities, caused by the proximity of the surface, etc.

The definition of the phenomenon of nano is complicated by the emergence of specific properties of materials that presents a major problem both in manufacturing and in the experimental study. For example, single crystal silicon, which is used in solid-state electronics, is difficult to obtain in a powdery state when we can talk about his nano-properties, because, after passing through the size threshold, the nanograins stick together and oxidize rapidly. At room conditions the latter may lead to an explosion.

Information about the fundamental properties of new really nanoscale materials in some cases is still fragmented and contradictory, hindering the development of real technologies, in particular, of solid-state nanoelectronics. 
наноструктур требует достаточно длительного времени, но в настоящее время процесс готов к использованию в промышленности. Выявлен ряд новых особенностей, присущих только ионному пучку, которые при правильном учете позволяют получить рекордные результаты. Однако незнание этих особенностей может приводить ко многим практическим трудностям [5].

Современная технология производства изделий микроэлектроники в своем развитии движется по путям уменьшения топологических размеров и увеличения степени интеграции, внедрения новых материалов, перехода к трехмерной интеграции, а также появления гибридных устройств и приборов, работающих на новых физических принципах [6]. Развитие микроэлектроники происходит путем ее эволюции в наноэлектронику, то есть с переходом через размерные пороги, при которых резко изменяются электрофизические, структурные, механические, оптические и другие свойства материалов и структур, что необходимо учитывать как при формировании и реализации технологического цикла их изготовления, так и при построении системы контроля параметров.

Электрофизические и оптические свойства объектов в состоянии размерного квантования, а также магнитные свойства в данной работе практически не рассматриваются, поскольку их учет и обсуждение проводятся на стадии реализации принципов функционирования прибора и его конструирования. Не рассматриваются также такие характерные для наноструктур эффекты, как туннелирование, баллистические эффекты и т.д. Предметом же обсуждения являются особенности изменения структуры и механических свойств, которые рассматриваются с точки зрения их влияния на результат контрольно-измерительных операций, сопровождающих процессы формирования.

Выбор в пользу исследования именно этих групп параметров обусловлен тем обстоятельством, что большая часть измерений в технологическом цикле производства ИС касаются геометрических и структурных параметров получаемых приборных элементов. Предлагаемые подходы позволяют приблизиться к реализации процессов наноэлектроники, когда проектные нормы переходят через либо эмпирические, либо теоретические размерные пороги, причем учет таких изменений необходим для получения достоверных результатов контроля геометрических параметров структур.

\section{ИЗМЕНЕНИЯ СТРУКТУРЫ И МЕХАНИЧЕСКИХ СВОЙСТВ ОБЪЕКТОВ В НАНОДИАПАЗОНЕ}

Рассмотрим некоторые изменения, которые происходят при развитии технологии микроэлектроники в область наноразмеров и которые в последнее время достоверно установлены, однако не всегда учитываются при формировании технологических циклов изготовления малоразмерных структур и еще реже принимаются во внимание при разработке методологии их контроля.
The development of a new scientific field is linked with the emergence of new areas in the scientifictechnical terminology. For example, the term "nanoindustry" needed a special explanation in the literature [1]. On the other hand, seemingly clear terms can sometimes mislead. For example, terms "nanoconductor" and "nanowire" are often confused and incorrectly used.

of course, the new area requires the HR development for research, education and technology taking into account the ultrafast development of scientific bases of laboratory and technological approaches [2].
New scientific and technical sphere is acquiring a special importance, in our view, at the transition to commercialization of scientific results, ideas, new features and technologies. The difficulties arising force us to seek fundamentally new approaches to the research, creation of technological foundations, the design and production of new materials, technological environment and equipment. At the same time, existing technological capabilities require either excessive costs or new ways, and sometimes drastic changes. And even well-known and well enough mastered indus try technologies during creation of nanoscale objects in the electronics show new opportunities, creating new challenges, requiring constant attention of researchers and bringing forward new principles of interaction between scientists and engineers that can be combined by the concept of "scientific support of technology". The latter is a continuous process, not frag mentary contacts.

In connection with the above considerations, let's consider two typical situations. The first one is connected with the use of 
Особенности структуры, связанные с изменением фундаментальных параметров объектов, такие как энергия связи атомов с узлом кристаллический решетки (или узлом упорядоченного квазижидкого состояния), концентрация равновесных для данной температуры дефектов структуры (подвижных вакансий и междоузельных атомов, либо их комбинаций), а также роль поверхности при формировании структурных свойств будет рассматриваться либо с точки зрения известных к настоящему времени фактов и представлений, либо с позиций гипотетического описания возможных эффектов, которые нуждаются в экспериментальной проверке. Структурные параметры нанообъекта определяют многие его свойства, включая температуру плавления, радиационную стойкость, фазовые переходы монокристалл-аморфное состояние, диффузионные процессы и т.д. Следует отметить, что определенную информацию об упомянутых выше параметрах наноструктур можно получить из анализа приповерхностных свойств монокристаллов, обнаруженных и описанных ранее.

По мнению авторов, пока не существует методов детального численного рассмотрения параметров элементарной ячейки в пределах нанообъекта. Заметим однако, что ряд наблюдавшихся эффектов могут быть напрямую связаны с другими экспериментально наблюдаемыми и описанными ранее явлениями. Например, резкое уменьшение температуры плавления нанообъекта может быть сопоставлено с наблюдавшимся ранее эффектом "локального анизотропного плавления" [7] в приповерхностных слоях монокристаллического кремния, что объяснялось наличием в них структурных дефектов, уменьшением энергии связи атома с узлом кристаллической решетки и, соответственно, увеличением концентрации равновесных структурных дефектов в этих слоях, а также поведением структурных дефектов внутри нанообъекта, включая их зарождение и аннигиляцию. Особо следует рассмотреть изменения равновесной концентрации дефектов при данной температуре. С учетом этого параметра необходимо изучать и эффекты, связанные с радиационным воздействием на нанообъекты, включая повышение радиационной стойкости [8], а также радиационно-стимулированную аморфизацию монокристаллов [9]. Здесь же необходимо учитывать роль ближних пар Френкеля и состояние поверхности нанообъекта.

Сначала остановимся подробнее на поликристаллических материалах, играющих важную роль в тонкопленочной полупроводниковой технологии. В настоящее время установлено, что изменение механических характеристик обусловлено в значительной степени характером микроструктуры наноматериала $[10,11]$. Например, значение микротвердости и пластичности зависят от размера зерна и плотности дислокаций в поликристаллическом материале. В классическом представлении данные закономерности явным образом не учитывались, однако эксперименты, проведенные в последнее десятилетие, убедительно photolithography in the field of ultra-small sizes, where optical devices have a new design features due to the move into a remote part of the UV range, which leads to a sharp rise in the cost of the equipment. In upcoming articles, we will tell you about developed in Russia industrial approaches, which are based on the use of a focused x-ray beams. This possibility has already been discussed at Mikron PJSC and can be very promising.

Another example concerns applications of the method and equipment for ion implantation and synthesis. This widespread technology is practically not used in creation of nanoscale (quantum-dimensional) structures to obtain essentially new devices and IC that combines features of integrated electronics and photonics. International literature contains quite a lot of information about this area, however, quantum-sized emitting structures on the basis of the germanium-silicon in the vast majority of cases are made using molecular beam epitaxy. The first and only works on the use of ion implantation [3, 4] showed that the preparation of the ion synthesis of $\mathrm{Si}-\mathrm{Ge}$ nanostructures requires quite a long time, but now the process is ready to use in the industry. A number of the new features inherent only to an ion beam, which at the correct use allow to obtain record results, is revealed. However, ignorance of these features may lead to many practical difficulties [5].

Up-to-date production technology of microelectronic components develops towards reducing the topological sizes, increasing the degree of integration, introducing new materials, transitioning to advanced packaging and also creating of hybrid devices running on new physical 
показали, что механические и пластические свойства наноматериалов существенно зависят от размера наночастиц [12]. Определение механизмов выявленных закономерностей является предметом для научных исследований. Оба фактора - микроструктура наноразмерного материала и размер исследуемого объекта - играют важную роль в изменении механических характеристик.

Для поликристаллических материалов в случае последовательного уменьшения размера кристаллитов особый интерес традиционно представлял вопрос взаимодействия структурных дефектов с границами зерен. Согласно классического закона Холла - Петча, границы зерен выступают в качестве ограничивающего фактора для движения дислокаций, что выражается в увеличении микротвердости и предела текучести поликристаллического материала при уменьшении размера зерна. Однако при рассмотрении нанокристаллических материалов с размерами зерен менее нескольких десятков нанометров описание пластической деформации требует учета широкого круга явлений, связанных со взаимодействием между структурными дефектами и границами кристаллитов $[13,14]$.

Особенности малоразмерных кристаллических объектов с учетом изменения прежде всего механических свойств (микротвердости, прочности, и т.д.) наиболее наглядно демонстрируются в одной из первых работ по их моделированию [15]. В работе наглядно показывается, как меняются механические свойства при прохождении через размерный порог. Результаты модельного эксперимента в дальнейшем были подтверждены экспериментально и будут обсуждены ниже.

Отметим влияние поверхности наноразмерного объекта на электрические, механические и другие его характеристики. Если в обычной технологии можно разделить свойства материала в объеме и его приповерхностных областях, то в данном случае влияние состояния поверхности резко возрастает и во многих случаях, как будет показано ниже, определяет свойства самого объекта, в том числе в ходе технологических операций.

В статье [12] с помощью просвечивающей электронной микроскопии высокого разрешения исследуется поведение наночастиц серебра (<10 нм в диаметре) при деформации (рис.1). В этом исследовании наночастица помещалась на острие вольфрамовой иглы, давление создавалось микроманипулятором, изготовленным из монокристаллического $\mathrm{ZrO}_{2}$. Поведение наночастиц авторы называют псевдоэластичным (квазижидким), подразумевая под этим, что под напряжением частицы сжимаются, а после его снятия восстанавливают свою исходную форму. При этом вещество остается кристаллическим во время всего процесса.

Память формы объясняется минимизацией капиллярной энергии, то есть остаточная форма - это энергетический компромисс между поверхностной энергией наночастицы и энергией границы раздела Ag-W. В качестве механизма, объясняющего эволюцию формы частицы, можно предложить поверхностную диффузию. principles [6]. The development of microelectronics occurs through its evolution to nanoelectronics, i.e. with the transition through the size thresholds that change sharply electrophysical, structural, mechanical, optical and other properties of materials and structures that need to be taken into account in the formation and implementation of the process cycle of their production, and in the design of the control system of parameters.

Electrophysical and optical properties of objects in a state of dimensional quantization and magnetic properties are not considered in this work, since their consideration and discussion are carried out at the stage of implementation of the principles of operation of the device and its design. Also such typical for nanostructures effects as tunneling, ballistic effects etc. aren't considered. The subject of the discussion are the features of change of structure and mechanical properties, which are considered from the point of view of their influence on the result of measuring operations, accompanying the process of formation.
The choice in favor of the study of these groups of parameters is caused by the fact that the majority of measurements in the production cycle of IC relate to the geometric and structural parameters of the obtained elements. The proposed approaches allow to approach the implementation of processes of nanoelectronics when the design rules pass through either empirical or theoretical size thresholds, and the accounting of such changes is necessary to obtain reliable results of the control of the geometric parameters of the structures. 
a)
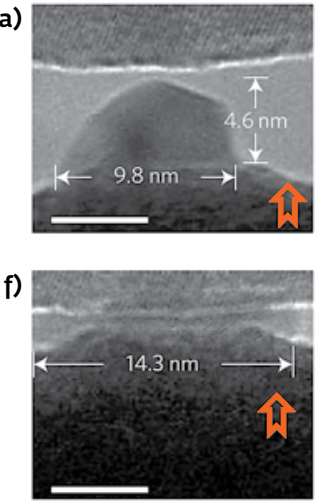
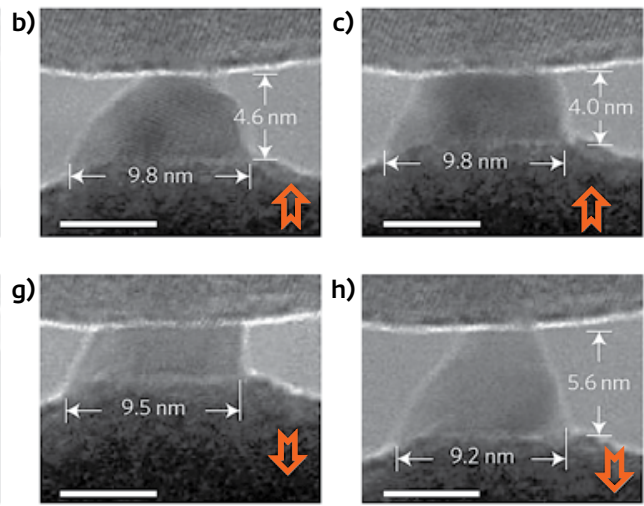
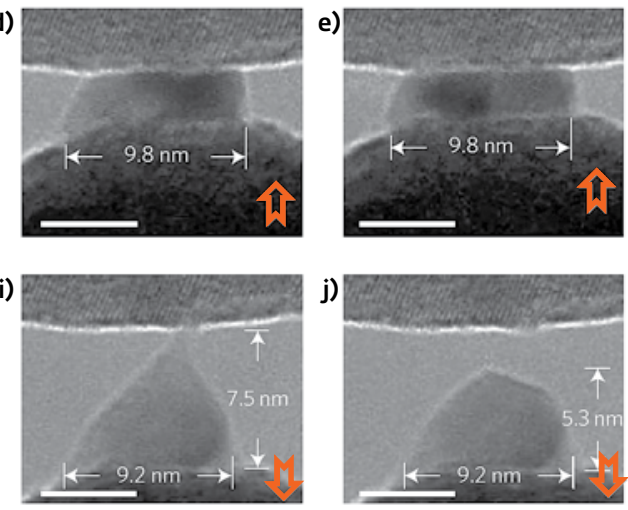

Puc.1. Эволюция формы наночастицы Ag при приложении (a-f) и последующем снятии (g-i) нагрузки [12]

Fig.1. Evolution of shape of Ag nanoparticle during loading (a-f) and subsequent unloading ( $g-i)$ [12]

Приложенное напряжение может быть уменьшено путем перемещения атомов с поверхности наночастицы к интерфейсам Ag-W или $\mathrm{Ag}-\mathrm{ZrO}_{2}$ и роста новых атомарных плоскостей.

Авторами работы [16] зарегистрирован спонтанный фазовый переход наноразмерных частиц $\mathrm{PdSi}$ из кристаллического состояния в аморфное, вызванный только уменьшением формы наночастицы без приложения каких-либо внешних воздействии (рис.2). Такое поведение авторы работы объясняют с помощью классических представлений - из условия минимализации свободной энергии Гиббса, которую они представляют как суперпозицию свободной энергии поверхности (возрастающей с ростом размера наночастицы) и свободной энергии объемного материала (уменьшающейся с ростом размера наночастицы).

Переход объекта через размерный порог приводит к резкому изменению структуры и связанных с ней свойств. Прежде всего, это касается состояния упорядоченности атомов, которое в предельных случаях может быть кристаллическим либо аморфным. Однако, как показано в [16], само по себе изменение размера вблизи величины порога не влияет на структуру.

\section{CHANGES IN STRUCTURE AND MECHANICAL PROPERTIES AT NANOSCALE}

We will consider some of the changes that occur in the development of microelectronics technology in the area of nanosizes and which in recent years are well established, however not always taken into account when forming the process cycles of manufacturing low-sized structures and even more rarely taken into account when developing the methodology of their control.

Features of the structure associated with changes in fundamental parameters of objects such as the binding energy of the atoms with a host of crystal lattice (or a node in an ordered quasi-liquid state), the equilibrium concentration for the temperature of structural defects (moving vacancies and interstitial atoms or their combinations), as well as the role of the surface in the formation of structural properties will be considered either from the viewpoint of currently known facts and ideas, either from the standpoint of a hypothetical description of the possible effects, which need experimental verification. The structural parameters of the nanoobject define many of its properties, including melting point, radiation resistance, phase transitions of the crystal-amorphous state, diffusion processes, etc. It should be noted that certain information on the above-mentioned parameters of nanostructures can be obtained from the analysis of the near surface properties of single crystals, discovered and described earlier.

According to the authors, there are as yet no numerical methods detailed consideration of unit cell parameters within the nanoobject. We will notice however that some of the observed effects can be directly associated with other 


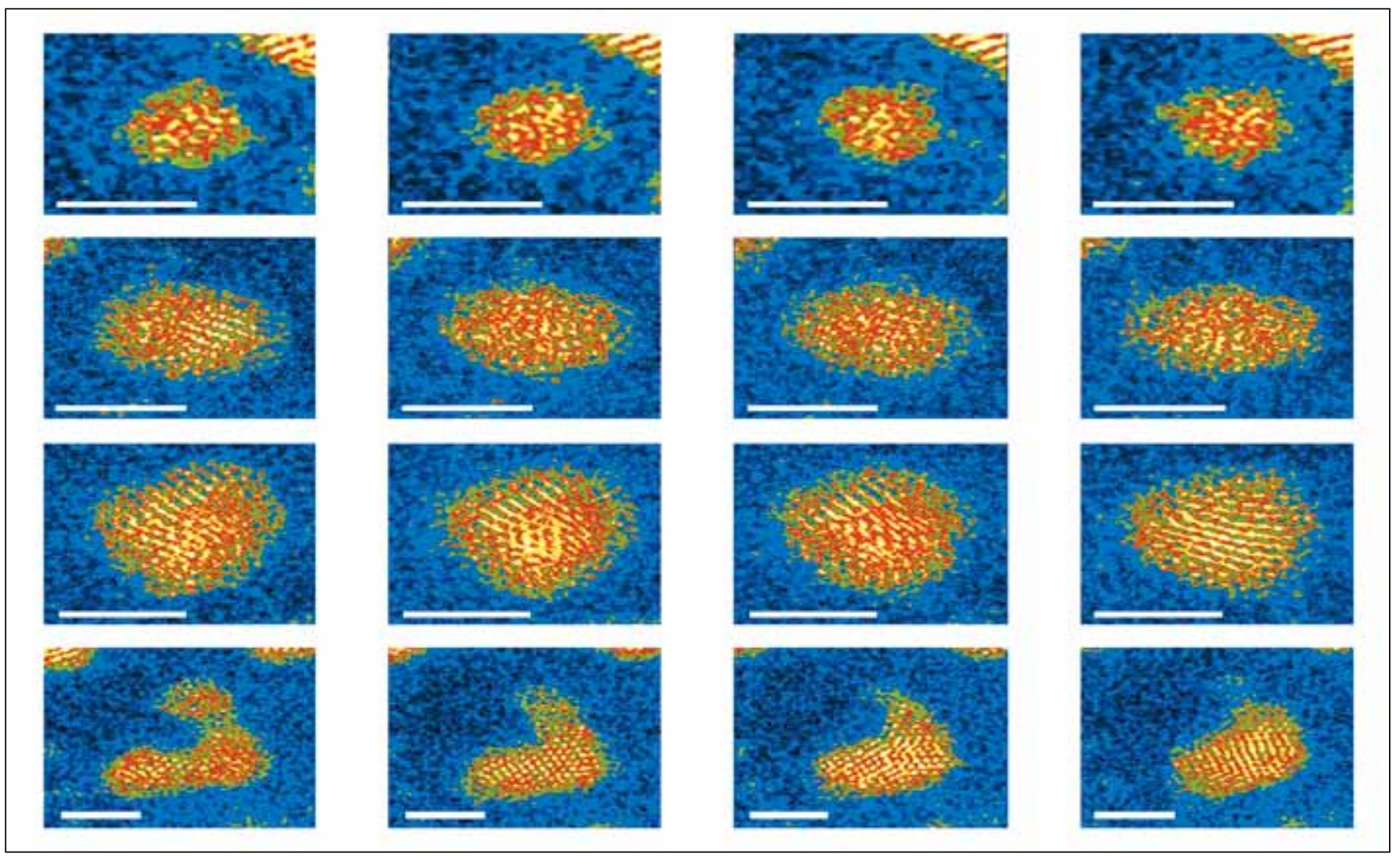

Рис.2. Обработанные ПЭМ-изображения, показывающие эволюцию структуры во времени для частиц с характерным размером 1,9 нм (a), 2,4 нм (b) и 3,0 нм (c): a - стабильно аморфная структура; b- кристапичческая структура; с - частица не имеет стабильной структуры и претерпевает последовательные фазовые превращения; $d$-процесс слияния трех аморфных частиц (полученная частица приобрела кристаличческую структуру). Все масштабные пинейки - 2 нм [16]

Fig.2. TEM images showing evolution of structure in time for particles with characteristic size of $1.9 \mathrm{~nm}$ (a) $2.4 \mathrm{~nm}$ (b) and $3.0 \mathrm{~nm}(c)$ : $a$ - stable amorphous structure; $b$-crystal structure; $c$ - particle has no stable structure and undergoes successive phase transformations; $d$ - merging three of amorphous particles (particle acquire crystalline structure). All scale bars are $2 \mathrm{~nm}$ in size [16]

experimentally observed and previously described phenomena. For example, a sharp decrease in the melting temperature of the nanoobject can be associated with previously observed effect of "anisotropic local melting" [7] in near-surface layers of monocrystalline silicon, which was explained by the presence of structural defects, a decrease of the binding energy of the atom with the lattice site and, consequently, an increase in the concentration of the equilibrium structural defects in these layers, as well as by the behavior of the structural defects inside the nanoobject, including their nucleation and annihilation. Especially it is necessary to consider changes of the equilibrium concentration of defects at a given temperature. Taking into account this parameter it is necessary to examine the effects associated with radiation exposure to nanoobjects, including improved radiation resistance [8] and radiation-induced amorphization of single crystals [9]. Here it is necessary to consider the role of neighbor Frenkel pairs and surface condition of the nanoobject.

First, let us dwell on polycrystalline materials play an important role in thin film semiconductor technology. Currently, it is established that the change in mechanical properties is largely caused by the nature of the microstructure of nanomaterials $[10,11]$. For example, the value of microhardness and plasticity depend on the grain size and the dislocation density in a polycrystalline material. In the classic view, these regularities explicitly weren't considered, however, the experiments conducted in the last decade have convincingly shown that the mechanical and plastic properties of nanomaterials strongly 
Приведенные выше экспериментальные факты о возможности перехода нанообъектов в новое фазовое состояние при изменении размера являются совершенно новыми и требуют дополнительной проверки. Однако уже сейчас появляются предложения об использовании эффекта в микроэлектронной технологии, в частности, о применении квантово-размерных жидких кристаллов [17].

Другие особенности материала связаны с размером кристаллита. Достаточно широко обсуждалась возможность снижения температуры плавления при уменьшении размера кристаллита [18]. Характерный пример рассмотрен в [19]. Здесь уместно упомянуть, что изменение свойств с уменьшением размера объекта после порогового значения можно связать с экспериментами по наблюдению "локального анизотропного травления" [7]. Сам по себе эффект связывается с повышенным числом дефектов структуры вблизи поверхности и уменьшением энергии связи атома в узле кристаллической решетки. Уместно напомнить также, что исследования радиационных эффектов в кристаллической решетке кремния показали зависимость энергии радиационного дефектоообразования от температуры (уменьшается с нагревом кристалла и становится равной нулю при температуре плавления) [20]. Для нанокристаллов эксперименты по уменьшению энергии дефектообразования при нагреве пока не проведены. Другим важным эффектом, связанным с параметрами кристаллической решетки, является изменение радиационной стойкости и радиационного порога фазового перехода "монокристалл - аморфное состояние" при уменьшении объекта ниже размерного порога.

Одним из показательных эффектов, связанных с изменением структуры при уменьшении размеров объекта, является радиационная стойкость. Это явление было впервые зафиксировано при изучении свойств нанообъектов (углеродных нанотрубок) на космических кораблях, где существенным является эффект радиационных повреждений [21].

В дальнейшем эффект был обнаружен и подробно исследован на кремниевых наноразмерных структурах (порошки, пористый кремний) [22], а также на многослойных металлических объектах [23]. В последнем исследовании авторы облучали ряд многослойных тонкопленочных структур $\mathrm{Nb}-\mathrm{Cu}$ с различной толщиной слоев $(2,5,5,40$ и 100 нм) ионами гелия с энергией 33 и 150 кэВ, дозой $6 \cdot 10^{16}-1,5 \cdot 10^{17} \mathrm{~cm}^{-2}$ при комнатной температуре. При толщинах слоев менее 20 нм не был выявлен "блистеринг" после облучения. Исследование проводилось с помощью ПЭМ высокого разрешения. Эффект объясняется тем, что энергия формирования точечных дефектов (вакансий) на границе раздела нанокомпозита $\mathrm{Cu}-\mathrm{Nb}$ намного меньше, чем в монокристаллическом материале. Интерфейс является эффективной областью стока подвижных радиационных дефектов.

Также было исследовано влияние поверхности на радиационную стойкость. Сам эффект связан depend on the nanoparticle size [12]. Determination of the mechanisms of the discovered regularities is a subject for scientific research. Both factors - microstructure of nanoscale material and size of the studied object play an important role in changing the mechanical characteristics.

The interaction of structural defects with the grain boundaries traditionally was of special interest for polycrystalline materials in case of the sequential decrease of the crystallite size. According to the classical law of Hall-Petch, the grain boundaries serve as a limiting factor for the movement of dislocations, resulting in the increase of microhardness and yield stress of polycrystalline material at the decreasing of grain size. However, when studying nanocrystalline materials with grain size less than several tens of nanometers, the description of plastic deformation requires consideration of a wide range of phenomena related to the interaction between structural defects and boundaries of the crystallites $[13,14]$.

Features of small crystalline objects taking into account the changes primarily of mechanical properties (microhardness, strength, etc.) are most clearly demonstrated in one of the first works on their modelling [15]. The paper clearly shows how mechanical properties change when pass ing through the size threshold. The results of the model experiment were further confirmed experimentally and will be dis cussed below. We will note influence of a surface of a nanoscale object on the electrical, mechanical and other characteristics. If the conventional technology allow to divide the material properties in the volume and surface areas, then in this case the influence of the surface state increases 


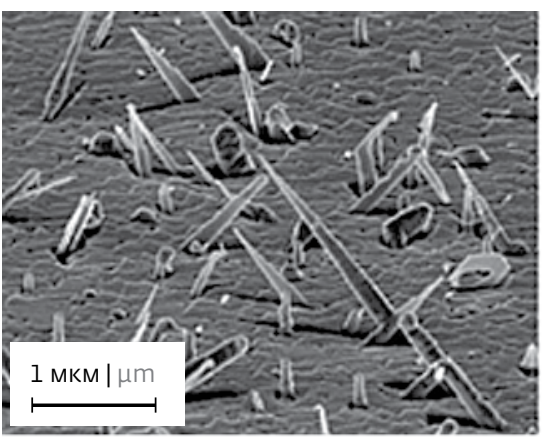

a)

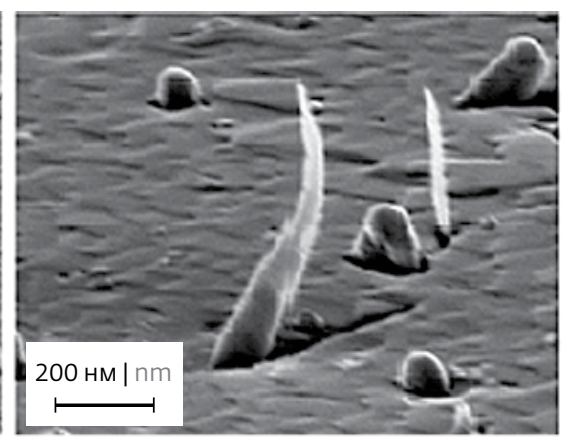

b)

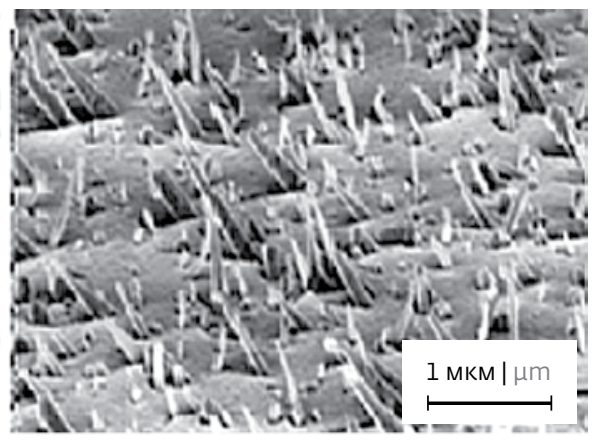

c)

Рис.3. Изгибание при ионной имплантации и рекристаллизация при последующем отжиге кремниевых нанопроволок: a - РэМ образца после получения нанопроволок Sі, имеющих характерный радиус у основания $49 \pm 16$ нм; $b$ - деформация нанопроволоки после имплантации ионами Gе дозой $1 \cdot 10^{15} \mathrm{CM}^{-2} \mathrm{C}$ энергией $45 \mathrm{kэB;} \mathrm{c}-$ после отжига при $t=600^{\circ} \mathrm{C}$ нанопроволоки вернулись в исходное состояние [31]

Fig.3. Bending of silicon nanowires at ion implantation and subsequent recrystallization during annealing: a-SEM image of sample after obtaining Si nanowires with typical radius of $49 \pm 16 \mathrm{~nm}$ at base; $b$-deformation of nanowire after implantation of Ge ions at dose of $1 \cdot 10^{15} \mathrm{CM}^{-2}$ with energy of $45 \mathrm{keV} ; \mathrm{c}$ - after annealing at $t=600^{\circ} \mathrm{C}$, nanowires returned to its original state [31]

с прохождением компонентов пары Френкеля через границу раздела, и ее влияние на радиационное накопление дефектов можно также связывать с опубликованными результатами для монокристаллов [9], где было показано, что поля упругих напряжений, определяемые присутствием на поверхности кремния диэлектрических пленок $\mathrm{SiO}_{2}$ либо $\mathrm{Si}_{3} \mathrm{~N}_{4}$, в силу противоположных воздействий (растяжение, сжатие) могут управлять разделением дефектов, рождающихся при радиационном облучении, в частности, при ионной имплантации [24].

Отметим также, что при рассмотрении радиационных повреждений нанокристаллов следует учитывать и роль компонентов ближних пар Френкеля, которой при описании радиационных эффектов в объемных монокристаллах считается целесообразным пренебрегать [25]. dramatically and in many cases as will be shown below determines the properties of the object itself, including during technological operations.

In [12] using high resolution transmission electron microscopy the behavior of silver nanoparticles (<10 $\mathrm{nm}$ in diameter) during deformation is investigated (Fig.1). In this study, the nanoparticle was placed on the tip of the tungsten needle, the pressure was created by the micromanipulator fabricated of single crystal $\mathrm{ZrO}_{2}$. The behavior of nanoparticles the authors call "pseudoelasticity" (quasi-liquid), implying that under pressure the particles are compressed but after its removal restore the original shape. At the same time, the substance remains crystalline during the whole process.

The shape memory is explained by minimization of the capillary energy, that is, the residual form is the energetic compromise between the surface energy of the nanoparticle and the energy of the Ag-W boundary. As a mechanism explaining the evolution of the shape of the particle, we can offer surface diffusion. The applied stress can be reduced by moving atoms from the surface of the nanoparticles to the interfaces of $\mathrm{Ag}-\mathrm{W}$ or $\mathrm{Ag}-\mathrm{ZrO}_{2}$ and by the growth of new atomic planes.

The authors of [16] have reported the spontaneous phase transition by nanoscale particles of PdSi from crystalline to amorphous states caused by only a decrease in the form of nanoparticle without application of any external stress (Fig.2). The authors explain such behavior with the help of classical ideas - from the condition of minimization of the Gibbs free energy, which they have represented as a superposition of the free energy of the surface (increasing with increasing size of nanoparticles) 
Эффект повышения радиационной стойкости связан с уменьшением размеров объекта ниже порогового уровня. Однако само по себе такое увеличение стойкости должно быть увязано с фазовым переходом "монокристалл - аморфное состояние" при облучении частицами, в частности при ионной бомбардировке. Этот фазовый переход подробно рассмотрен в работе [26], где экспериментально показано, что доза аморфизации для ионов в зависимости от их массы существенно меньше, чем для таких же ионов, использованных для аморфизации монокристаллов. Этот результат казалось бы противоречит гипотезе о радиационном накоплении дефектов в нанокристаллах, поскольку существующие модели аморфизации связывались с накоплением точечных дефектов, в частности вакансионных комплексов порядка $10^{20} \mathrm{~cm}^{-3}$. Модель, использованная в этой работе, предполагает существование вблизи поверхности предаморфизированных областей, что вполне подтверждено последующими исследованиями, так как в приповерхностных областях повышена концентрация равновесных дефектов. Отметим, что изучались нанокристаллы кремния, сформированные в диэлектрической матрице $\mathrm{SiO}_{2}$, что само по себе может стимулировать фазовый переход. Уменьшение размеров объектов с образованием нанокристаллов, как уже отмечалось, может приводить к аморфизации и без радиационных воздействий, что, по нашему мнению, связывается с повышенной концентрацией равновесных дефектов в таких объектах.
Рассмотрим теперь радиационную аморфизацию при ионной бомбардировке. В последние годы было опубликовано несколько работ, в которых исследовались электрофизические свойства ионно-имплантированных нанопроволок [27, 28], однако эффекты ионного облучения, связанные с введением дефектов кристаллической структуры, которые могли бы ограничить электрофизические характеристики имплантированных ионов примеси, до сих пор остаются практически не изученными. Недавно было обнаружено изгибание нанопроволок арсенида галлия под воздействием ионного облучения. Предположительно, главным механизмом этого изгибания является пространственное разделение междоузельных и вакансионных дефектов [29]. В этой связи следует обратить внимание на результаты наблюдения аморфизации в работе [30], где экспериментально исследовалась деформация кремниевых нанопроволок при облучении ионами. Механизм изгибания не был полностью изучен, однако было показано, что причиной деформации проволок служили механические напряжения, возникающие на границе раздела аморфной, полученной при облучении, и кристаллической фаз (рис.3). В работе показано, что уменьшение размера (диаметра вискерса) приводит к уменьшению дозы аморфизации.

В настоящее время основным методом механической обработки образцов на наноуровне является воздействие фокусированным ионным пучком (ФИП). Сфокусированные пучки ионов, and the free energy of the bulk material (decreasing with increasing size of nanoparticles).

The transition through the size threshold leads to a sharp change in the structure and related properties of the object. First of all, it concerns the state of ordering of atoms, which in extreme cases can be crystalline or amorphous. However, as shown in [16], the size changes near the threshold level does not affect the structure.

The above experimental facts about the possibility of switching of nanoobjects into the new phase state at change of the size are brand new and require further testing. However, the proposals to use effect in microelectronic technology, in particular, on the application of quantum-dimensional liquid crystals already appear [17].

Other features of the material are related to the size of a crystallite. The possibility of reducing the melting temperature with decreasing of the crystallite size have been discussed widely [18] A typical example is considered in [19]. It is appropriate to mention that the change in properties with decreasing size of the object after a threshold can be associated with experiments on "local anisotropic etching" [7]. By itself, the effect is associated with an increased number of structural defects near the surface and decrease of the energy of the atom in the lattice site. It is pertinent to recall also that the studies of radiation effects in the crystal lattice of silicon showed dependence of the energy of the radiation defect formation on temperature (decreases with heating of the crystal and becomes zero at the melting temperature) [20]. The experiments on reduction of energy of defect formation in nanocrystals upon heating have been not carried out. Another important effect related to the lattice parameters is 
обычно галлия (Ga+), позволяют локально травить и осаждать материал в наноразмерных областях. ФИП применяется, например, для прототипирования ИС [31], трехмерного анализа материалов и структур [32, 33], экстракции и подготовки образцов к электронной микроскопии [34, 35], исследования пороговых размерных свойств материалов и структур в нанотехнологиях [36, 37], а также во многих других областях. Однако ФИП-обработка не только удаляет приповерхностные атомы, но и смещает атомы нижележащих слоев от их состояния равновесия, вызывая каскады соударений и структурные повреждения [36]. Эти эффекты, типичные для процессов ионного излучения, вызваны бомбардировкой поверхности потоком тяжелых высокоэнергетических ионов, однако тот факт, что применяемые пучки плотно сфокусированы, вносит свои особенности в процесс расчета траекторий ионов и вызванных ими структурных повреждений $[38,39]$. Эффекты, связанные с обработкой ФИП, также могут быть причиной наблюдаемых изменений механических свойств нанообъектов [36, 40-42].

Повреждения, которые вносятся ФИПобработкой, включают аморфизацию поверхности [43], генерацию дефектов кристаллической решетки [44] и формирование интерсоединений между материалом образца и ионами пучка [45]. Эти данные необходимо учитывать при подготовке образцов к исследованию методами ФИП, особенно если речь идет о структурном или фазовом анализе. Как будет показано ниже, сама по себе обработка ФИП может вносить искажения в наблюдаемый результат, причем эти искажения могут наблюдаться на достаточно большом удалении от подвергшегося обработке участка.

Изменение свойств материала при воздействии ФИП было недавно описано в работе [49] на примере нанокристаллов золота. Сделано заключение, что такой технологический процесс приводит к существенным изменениям структуры монокристалла и должен всерьез обсуждаться с позиций применения в нанотехнологии электроники. Обнаруженные в [49] структурные изменения обсуждались на конференции ConFab 2017 [46]. Описанные в работе [47] результаты одного из обсужденных на данной конференции докладов, подробно представленные в статье [49], являются наиболее важными, судя по публикации в одном из последних номеров журнала Solid State Technology. Однако отметим, что подобное явление было детально описано нами в работе, проведенной на кремнии [50], и подтверждается результатами, которые будут подробно описаны ниже. Возможно, что ссылка на эти результаты отсутствует из-за того, что они получены для реально используемой технологии кремниевой электроники.

\section{ИССЛЕДОВАНИЯ ФИЗИЧЕСКИХ СВОЙСТВ КРЕМНИЕВЫХ НАНОСТРУКТУР}

B [50] на установке FEI Quanta 200 3D с помощью ФИП в монокристаллическом кремнии the change of the radiation resis tance and of radiation threshold of the phase transition "crys tal-amorphous state" in case of reducing the object below the size threshold.

One of the notable effects associated with the change in the structure at the reducing of the size of the object is the radiation resistance. This phenomenon was first observed when studying the properties of nanoobjects (carbon nanotubes) on the spacecraft, where the effect of radiation damage is significant [21].

Then the effect was discovered and investigated in detail on silicon nanoscale structures (powders, porous silicon) [22], and multilayer metallic objects [23]. In the latter study, the authors irradiated a series of thin-film multilayer Nb-Cu structures with different thickness of layers (2.5, 5, 40 and $100 \mathrm{~nm}$ ) by helium ions with energies of 33 and $150 \mathrm{keV}$, dose of $6 \cdot 10^{16}-1.5 \cdot 10^{17} \mathrm{~cm}^{-2}$ at room temperature. When the thickness of layers was less than $20 \mathrm{~nm}$, there was no "blistering" after exposure. The study was conducted with the help of high resolution TEM. The effect is explained by the fact that the energy of formation of point defects (vacancies) at the interface of $\mathrm{Cu}-\mathrm{Nb}$ nano-composite is much smaller than in the single-crystal material. The interface is an effective area of drain of mobile radiation defects.

It was also investigated the effect of surface on radiation resistance. The effect itself is associated with the passage of the components of Frenkel pairs through the interface, and its influence on the accumulation of radiation defects can also be associated with published results for single crystals [9], where it was shown that the fields of elastic stresses caused by the presence of dielectric films of $\mathrm{SiO}_{2}$ or $\mathrm{Si}_{3} \mathrm{~N}_{4}$ 

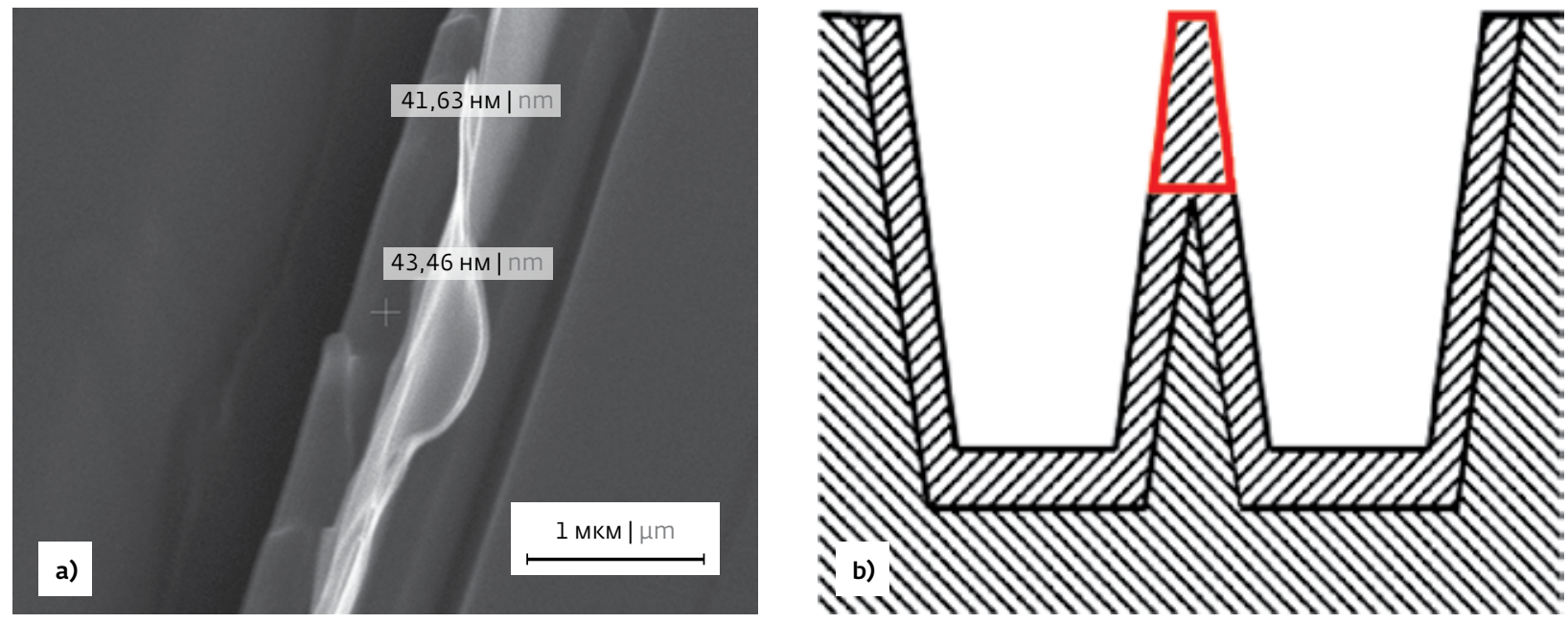

Рис.4. Проявление размерных пластических свойств у одномерной наноразмерной структуры, полученной травлением монокристапичческого кремния с помощью ФИП: $a$ - РЭМ структуры, которая проявила пластические свойства; $b$ - схема профиля структуры. Область, выделенная красным, является полностью аморфной и обладает пластичностью. Она coответствует изогнутой области на (а)

Fig.4. Demonstration of size-dependent plastic properties of one-dimensional nanoscale structure obtained by etching of monocrystalline silicon using FIB: $a$-SEM image of structure that has shown plastic properties; $b$ - profile of structure. Red area is completely amorphous and has plasticity. It corresponds to curved region in (a)

была вытравлена одномерная протяженная структура. Энергия ионов составляла 5 КэВ, ток пучка - 1 нА. Травление образца проводилось в режиме сканирования с заданным временем 20 мкс в каждой точке траектории.
Диаметр зонда составлял около 2,75 мкм. В работе использовались пластины монокристаллического кремния с ориентацией (100). Травление образца проводилось по параллельным траекториям таким образом, чтобы между on the surface of the silicon, due to the opposite effects (tension, compression) can control the separation of the defects born during irradiation, in particular during ion implantation [24].

We will note also that when considering radiation damage of nanocrystals, it is necessary to take into account the role of the components of the neighbor Frenkel pairs, which in the description of radiation effects in bulk single crystals are not considered [25].

The effect of increasing radiation resistance is associated with a decrease in the size of the object below the threshold level. However, by itself such an increase of resistance should be linked to the phase transition of "single crystal-amorphous state" during irradiation with particles, in particular during the ion bombardment. This phase transition is considered in detail in [26] where it is experimentally shown that the dose of amorphization of ions depending on their mass is significantly less than for the same ions used for the amorphization of single crystals. This result would seem contradicts the hypothesis about the accumulation of radiation defects in nanocrystals, because the existing models of amorphization are associated with the accumulation of point defects, in particular of vacancy complexes of the order of $10^{20} \mathrm{~cm}^{-3}$. The model used in this work presupposes the existence of near-surface pre-amorphizated areas, which is confirmed by subsequent studies, as the near surface areas contains the increased concentration of equilibrium defects. It should be noted that the silicon nanocrystals formed in a dielectric $\mathrm{SiO}_{2}$ matrix, which in itself can stimulate the phase transition, were studied. Reducing the size of the objects 
двумя канавками оставался наноразмерный зазор (рис.4), величиной которого можно было управлять путем переноса координаты начальной точки одной из траекторий сканирования в направлении, перпендикулярном направлению сканирования. Управление велось таким образом, чтобы этот зазор уменьшался от канавки к канавке.

Полученная рельефная структура имела трапециевидное сечение (рис.4b). Когда размер рельефа приблизился к 40 нм (в верхней части), произошло его самопроизвольное изгибание (рис.4а). Таким образом, в данном эксперименте материал проявил пластические свойства, которые не характерны для монокристаллического кремния, обладающего высокой твердостью. Под воздействием ФИП в материале одновременно происходят два процесса: распыление атомов приповерхностного слоя и пластическое течение, связанное с введением избыточной концентрации радиационных подвижных дефектов. Приповерхностный слой, образующийся в том числе на стенках кратера травления ФИП, имеет свойства, отличные от свойств основного материала.

Рассмотрим случай, когда два кратера травления расположены в непосредственной близости друг от друга. На стенках каждого из них имеются области с повышенной концентрацией неравновесных радиационных дефектов. При сближении этих областей, начинается их взаимное влияние друг на друга, и, в конце концов, они полностью перекрываются. Общая концентрация дефектов возрастает, что сопровождается ростом механических напряжений в этом слое и, как следствие, пластическим течением материала. При преодолении пороговой концентрации дефектов может происходить также полная аморфизация материала в рассматриваемой области.

Причины этого явления, на первый взгляд, связаны с внедрением избыточной концентрации дефектов при обработке ФИП. Однако, отметим, что нижняя часть полученной структуры на рис.4, а также часть, имеющая большие поперечные размеры, не проявили пластических свойств, хотя также подвергались воздействию ФИП. Следы трещин в нижней части рис.4 свидетельствуют о том, что структура проявила свойства твердого вещества. Отсюда можно сделать вывод, что определяющее значение для проявления пластических свойств в данной структуре имел именно размерный параметр. Часть структуры, перешедшая через размерный порог, проявила пластические свойства, в то время как не перешедшая часть проявила повышенную твердость в соответствии с классическими представлениями, изложенными в законе Холла - Петча [11].

В работе [50] коллективом лаборатории РМТиА МИЭТ были исследованы особенности формирования наноразмерного рельефа на стенках кратера при травлении кремния фокусированным ионным пучком. Обнаружено, что в зависимости with the formation of nanocrys tals, as already noted, can lead to amorphization without radiation exposure, which, in our opinion, is associated with a higher concentration of equilibrium defects in such objects.

Let us now consider the radiation amorphization during the ion bombardment. In recent years there have been several works published which have investigated electrophysical properties of ion-implanted nanowires [27, 28], however the effects of ion irradiation that is related to the introduction of defects of the crystal structure, which could limit the electrophysical characteristics of the implanted impurities ions, still remain practically unstudied. Bending of gallium arsenide nanowires under the influence of ion irradiation was recently discovered. Presumably, the main mechanism of this bending is the spatial separation of vacancy and interstitial defects [29]. In this regard, we should pay attention to the results of observation of amorphization in [30], where the deformation of a silicon nanowire under ion irradiation was experimentally investigated. The bending mechanism has not been fully explored, however it has been shown that the deformation of the wires is caused by mechanical stress arising at the interface of the amorphous (obtained in the irradiation) and crystalline phases (Fig.3). It is shown that the reduction of the size (the diameter of the whiskers) leads to a decrease in the dose of amorphization.

Currently, the main method of mechanical treatment of samples at the nanoscale is the focused ion beam (FIB) technique. Focused beams of ions, typically of gallium (Ga+), allow to carry out local etching and deposition of the material in nanoscale areas. FIB is used, for example, in IC prototyping 
от условий эксперимента, образовавшиеся поверхности цилиндров отличаются от идеально гладких, так как формируются кольцеобразные наплывы, расположенные друг от друга на одинаковых расстояниях (рис.5). В этой работе для травления использовались ионы $\mathrm{Ga}+\mathrm{c}$ варьированием энергии от 5 до 30 КэВ и тока пучка от 1 до 20 нА. Травление образца проводилось при неподвижном положении пучка перпендикулярно поверхности образца. Время травления варьировалось от 1 до 50 мкс. В работе исследовалась зависимость наблюдаемых пластических явлений от ориентации монокристаллического кремния. Для пластин с ориентацией (111) и (100) зависимость наблюдаемых явлений от кристаллографической ориентации не наблюдалась. При плотности тока ионого пучка 2,16 мкA/см² отмечены ярко выраженные наплывы на стенках цилиндра (рис.5), а при снижении плотности тока до 1,07 мкA/см² образование наплывов отсутствовало.

Для изучения структурных свойств рассматриваемых образцов было выполнено исследование структуры образовавшихся наплывов. Из представленных на рис.6 изображений следует, что линии Кикучи слабо видны в области облучения ионами (рис.6а), в отличие от области без облучения (рис.6b). Остаточная видимость в необлученной области обусловлена тем, что дифракция происходит в поверхностном слое кремния с большей толщиной, чем у аморфизированного слоя. Исследование дифракции быстрых

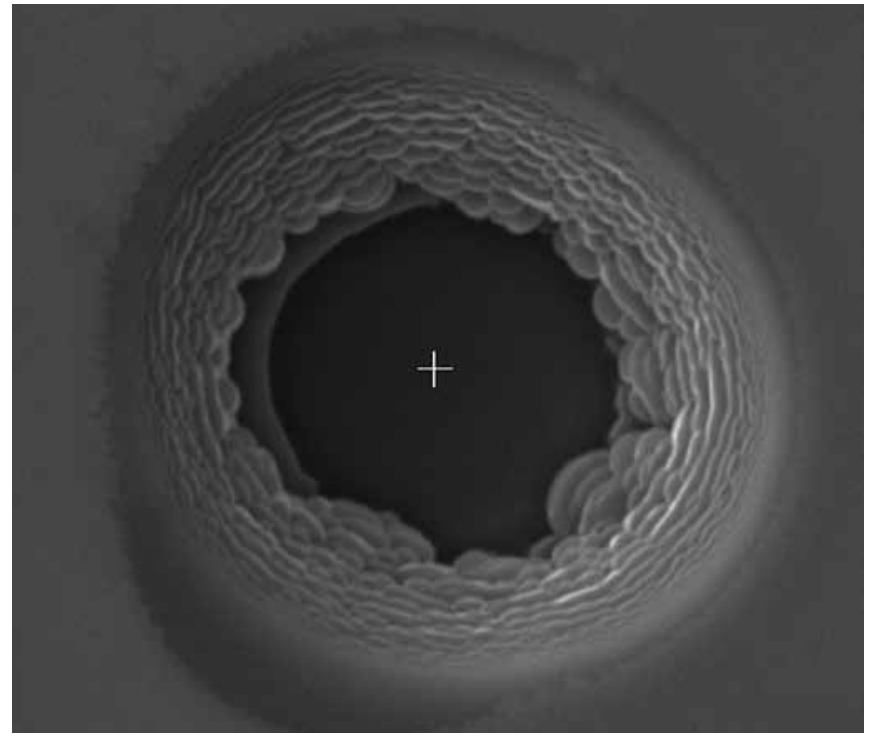

Puc.5. Волнообразные наплывы, образованные на стенках кратера травления монокристалпической пластины марки КДБ-10 (100) [54]

Fig.5. Wave-like formations on walls of crater of etching of КДБ10 (100) monocrystalline wafer [54]

электронов проводилось при ускоряющем напряжении 30 кВ, токе 9,7 нА, угле наклона исследуемой поверхности 70. При данных условиях электроны по большей части отражаются от поверхности, и лишь небольшая их часть с высокой энергией проникает на глубину около 150-200 нм.

Таким образом, экспериментально показано, что поверхность кратера является аморфизованной.
[31], three-dimensional analysis of materials and structures [32, 33], extraction and preparation of samples for electron microscopy $[34,35]$, study of the threshold dimensional properties of materials and structures in nanotechnology $[36,37]$, as well as in many other areas. However, FIB treatment not only removes the surface atoms, but also shifts the atoms of the underlying layers from their equilibrium state, causing a cascade of collisions and structural damages [36]. These effects that are typical for the processes of ion emission are caused by bombardment of the surface by the flow of heavy high-energy ions, however, the fact that the beams are tightly focused brings its own peculiarities into the process of calculation of the trajectories of ions and the resulting structural damages [38, 39]. The effects associated with the FIB treatment can also be the cause of the observed changes in the mechanical properties of nanoobjects [36, 40-42].

Damages caused by FIB treatment include amorphization of the surface [43], the generation of crystal lattice defects [44] and the formation of links between the sample material and ions of the beam [45]. These data should be considered when preparing samples to study using FIP, especially if we are talking about structural or phase analysis. As it will be shown below, by itself, the FIB treatment can contribute distortion in the observed result, and these distortions can be observed at a sufficiently large distance from the treated area.

The change in material properties when exposed by FIB was recently described in [49] on the example of nanocrystals of gold. It is concluded that this process leads to significant changes in the structure of the single crystal and should be discussed from the 
a)

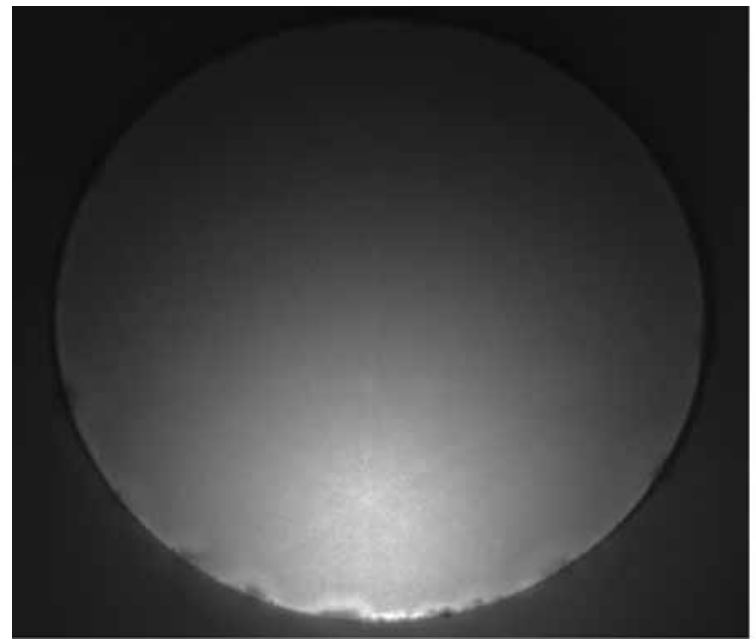

b)

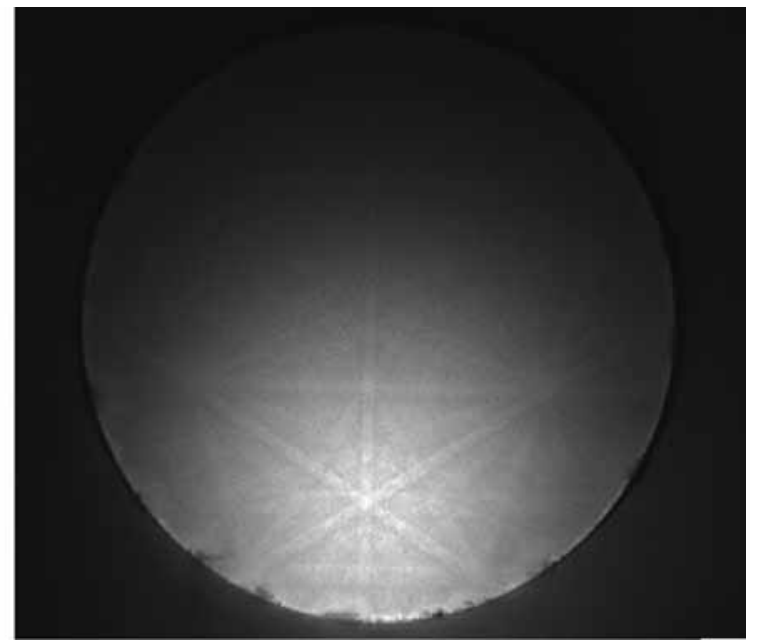

Рuc.6. Дифракция быстрых электронов в области (a) и вне области (b) облучения ионами

Fig.6. Diffraction of fast electrons in region (a) and outside of region (b) of irradiation by ions

Из того следует, что преобладающим механизмом в формировании стенок цилиндров является не перераспыление, а пластическое течение, связанное с введением избыточной концентрации подвижных радиационных дефектов. Можно сделать вывод, что в описанном эксперименте, выполненном в рамках исследования [50], зафиксирована зависимость процесса формирования периодических структур при ионном травлении от плотности тока ионного пучка и независимость от времени травления. Полученные результаты находятся в противоречии с классическими представлениями о формировании рельефа при ионном травлении за счет перераспыления материала, что заставило обсуждать альтернативные точки зрения на данный процесс. Альтернативный механизм, связанный с пластическим течением [48], обсуждался в мировой научной литературе совсем недавно. Также, отметим, что аналогичный эффект наблюдался для металлов в недавней standpoint of applications in electronics nanotechnology. Found in [49] structural changes were discussed at the ConFab 2017 conference [46]. Results of [47] that have been discussed at this conference (presented in detail in [49]) are the most important according to the publication in a recent issue of the Solid State Technology journal. However, it should be noted that a similar phenomenon was described by us in details in the work carried out on silicon [50] and is confirmed by the results that will be described in detail below. It is possible that the reference to these results is missing due to the fact that they were obtained for the actually used technology of silicon-based electronics.

\section{STUDY OF PHYSICAL PROPERTIES OF SILICON NANOSTRUCTURES}

In [50], an one-dimensional extended structure was etched in a single-crystal silicon with the use of the FEI Quanta 200 3D system and FIB technique. The ion energy of $5 \mathrm{Kev}$ at beam current of $1 \mathrm{nA}$ were used. Etching of the sample was carried out in scanning mode with a specified time of $20 \mu \mathrm{s}$ at each point of the trajectory. The probe diameter was around $2.75 \mu \mathrm{m}$. The wafers of monocrystalline silicon with orientation (100) were used in the project. Etching of the sample was carried out along parallel trajectories so that between the two grooves a nano-sized gap (Fig.4) remained, the value of which can be set by changing the coordinates of the initial point of the scanning trajectory in the direction that is perpendicular to the scanning direction. The control was conducted in such a way that this gap reduced from groove to groove.

The obtained relief structure had a trapezoidal cross-section 
статье [49], однако нашим коллективом этот эффект был открыт на несколько лет раньше [50].

Согласно современным представлениям, при облучении монокристаллической подложки ионным пучком, направленным к ее поверхности под некоторым углом $\theta$, меньшим критического, возникают каскады радиационных смещений, приводящие к направленному движению существенных потоков междоузельных и вакансионных дефектов вблизи поверхности и сопровождающиеся пластическим течением материала [48]. Плотность дефектов в возникающих радиационных каскадах значительна, что приводит к полной аморфизации приповерхностного слоя.

\section{ЗАКЛЮЧЕНИЕ}

Приведенные результаты показывают, что уменьшение элементов структуры вплоть до наноразмеров может приводить к кардинальным изменениям ее механических свойств, в связи с чем стоит обратить внимание на результаты по формированию наноструктуры рекордно малых размеров, продемонстрирован ной недавно фирмой IBM (транзисторная структура FinFet, выполненная по проектным нормам 7 нм) [51].

Особое внимание состоянию структуры в наноразмерных объектах необходимо уделять при рассмотрении результатов радиационных воздействий на нанообъекты. Резкое увеличение радиационной стойкости в нанообъектах [8], которое фиксируется по изменению функциональных свойств приборов, противоречит фактам уменьшения дозы аморфизации нанообъектов [26]. Эти вопросы отдельно обсуждались в работах [52], а также в ряде работ, выполненных в нашей лаборатории [7, 54]. Отметим, что фазовый переход при меньших (по сравнению с монокристаллом) дозах облучения связан, по нашему мнению, с накоплением критической дозы дефектов, в частности, вакансионных V-V центров [53], которая складывается из равновесной концентрации и неравновесной радиационной составляющей. В этом случае ожидается, что равновесная концентрация при данной температуре повышена [54].

В рамках предлагаемого единого подхода к рассмотрению свойств наноразмерных объектов, учитывающего взаимодействие подвижных дефектов с границами наноразмерных объектов, влияние поверхностей и границ раздела, можно развивать описание различных физических явлений, таких как аморфизация и пластическое течение твердых материалов. Переход объекта через размерный порог приводит к резкому изменению структуры и связанных с ней свойств. Прежде всего, это касается состояния упорядоченности атомов, которое в предельных случаях может быть кристаллическим либо аморфным. В опубликованной нами работе [50] показано, что радиационные процессы могут приводить к настолько существенным изменениям структуры, что на границах травления
(Fig.4b). When the size of the relief has approached $40 \mathrm{~nm}$ (at the top), his spontaneous bending has occured (Fig.4a). Thus, in this experiment, the material has shown plastic properties that are not typical for monocrystalline silicon with high hardness. Under the influence of FIB two processes occur simultaneously in the material: the sputtering of atoms of the surface layer and the plastic flow associated with the introduction of an excessive concentration of radiation mobile defects. Properties of the near-surface layer, which is formed including, on walls of a crater of FIB etching, differ from the properties of the basic material.

Let us consider the case when two craters of etching are located in close proximity to each other. The walls of each include a regions with a high concentration of nonequilibrium radiation defects. In case of approaching of these areas, begins their mutual influence on each other, and, in the end, they completely overlap. The total concentration of defects increases, which is accompanied by the growth of mechanical stresses in this layer and, as a result, by plastic flow of material. In case of overcoming threshold concentration of defects, a complete amorphization of the material in this area can also occurs.

The causes of this phenomenon, at first glance, are associated with the introduction of an excess concentration of defects at the FIB processing. However, it should be noted that the lower part of the structure in Fig.4, and a part having large lateral dimensions, hasn't shown plastic properties, although they are also exposed by FIB. Traces of cracks in the lower part of Fig.4 indicate that the structure showed the properties of solids. Thus, we can conclude that the the size parameter 
могут наблюдаться наплывы, связанные с формированием областей, обладающих пластическим течением. Этот же эффект подробно обсуждался на недавней конференции ConFab [47], а в работе [49] он был рассмотрен более подробно, однако ее результаты практически совпадают с результатами ранее опубликованной работы [50].

Рассмотренные размерные эффекты изменения механических свойств и структуры наноразмерных объектов необходимо учитывать при изготовлении образцов, пробоподготовке, а также при проведении исследований, так как они могут вносить искажения в наблюдаемый результат. Проявления квазижидких (аморфных) свойств возможны как при изготовлении, так и при исследовании образцов. Это касается не только процессов обработки и проведения контроля в лаборатории, но и технологического контроля in-situ.

Работа поддержана грантом Российского научного фонда, проект № 15-19-10054.

\section{ЛИТЕРАТУРА}

1. Герасименко Н.Н. Как готовить кадры для нанотехнологии // НАНОИНДУСТРИЯ. 2011. № 1. С. 50.

2. Гаврилов С.А., Герасименко Н.Н., Рыгалин Б.Н., Тимошенков С.П. Наноинженерия - воплощение нанотехнологии в реальной продукции // Нано- и микросистемная техника. 2009. №12. С. 3.
3. Gerasimenko N.N. et al. Quantum-dimensional structures produced by ion-implantation // Nuclear instruments and methods in physics research B. 2003. Vol. 206. P. 644.

4. Parkhomenko Yu.N., Belogorokhov A.I., Gerasimenko N.N. Properties of selforganized SiGe Nanostructures formed by ion implantation // Semiconductors. 2004. Vol. 38. No. 5. P. 572.

5. Balakleyskiy N.S., Gerasimenko N.N., Zaporozhan O.A. Room temperature nearIR photoluminescence and lasing from selforganized Ge QDs formed by ion implantation in silicon // Proc. Of Advanced Solid State Lasers conf., Japan. 2017.

6. The International Technology Roadmap for Semiconductors; URL: http://www.itrs2.net/ itrs-news.html.

7. Герасименко Н.Н., Гудаев Г.А., Двуреченский А.В. и др. Процесс аморфизации кремния при облучении тяжелыми ионами // Физика и техника полупроводников. 1986. T. 10. B. 7. C.1237.

8. Герасименко Н.Н., Смирнов Д.И. Радиационная стойкость наноструктур // Нанои микросистемная техника - М.: Новые технологии. 2008. № 9. С. 2.

9. Смирнов Л.С. Физические процессы в облученных полупроводниках. Монография, главы 5, 6. Новосибирск: Наука, 1977. 256 с.

10. Jang D. and Greer J.R. Plasticity in small-sized metallic systems: Intrinsic versus extrinsic size had decisive importance for the manifestation of plastic properties in this structure. Part of the structure, passed through the size threshold, has plastic properties, while the part that have not passed it showed increased hardness in accordance with classical concepts of the Hall-Petch [11].

In [50], scientists from MIET have investigated features of formation of nanoscale topography on the walls of the crater at the etching of silicon by focused ion beam. It is discovered that depending on the experimental conditions, the formed surfaces of the cylinders differ from perfectly smooth, as ring-shaped formations located from one another at equal distances arise (Fig.5). In this work, the etching by $\mathrm{Ga}+$ ions with varying the energy from 5 to $30 \mathrm{keV}$ and the beam current from 1 to $20 \mathrm{nA}$ have been carried out. The etching was carried out at a fixed position of the beam perpendicular to the sample surface. Time of etching was varied from 1 to $50 \mu$ s. In this project we have investigated the dependence of the observed plastic phenomena on the orientation of monocrystalline silicon. For wafers with orientation (111) and (100) the dependence of the observed phenomena on the crystallographic orientation was not identified. At a current density of the ion beam of $2.16 \mu \mathrm{A} / \mathrm{cm}^{2}$ the pronounced formations on the walls of the cylinder (Fig.5) were registered, while at reducing the current density to $1.07 \mu \mathrm{A} / \mathrm{cm}^{2}$ the formations were absent.

To investigate the structural properties of the considered samples, the study of the structure of the formations was performed. Images in Fig.6 show that the Kikuchi lines are poorly visible in the field of ion irradiation (Fig.6a), in contrast to the region without irradiation 
effect // Progress in Materials Science. 2011. Vol. 56(6). P. 654-724.

11. Greer J.R., Nix W.D. Size dependence of mechanical properties of gold at the sub-micron scale // Applied Physics. 2005. Vol. 80. Iss. 8. P. 1625-1629.

12. Sun J., He L. et al. Liquid-like pseudoelasticity of sub-10-nm crystalline silver particles // Nature Materials. 2014. Vol. 4105. P. 1.

13. Ashkenazy Y., Averback R.S. Irradiation Induced Grain Boundary Flow: A New Creep Mechanism at the Nanoscale // Nano Letters. 2012. Vol. 12(8). P. 4084.

14. Mayr G., Ashkenazy Y., Albe K. et al. Mechanisms of Radiation-Induced Viscous Flow: Role of Point Defects // Physics Review Letters. 2003. Vol. 90. No 5. P. 055505.

15. Hawa T., Henz B., Zachariah M. Computer Simulation of Nanoparticle Aggregate Fracture // Mater. Res. Soc. Symp. Proc. 2008. Vol. 1056.

16. Sun Y.T., Cao C.R. Real-space imaging of nucleation and size indused amorphization in PdSi nanoparticles // Intermetallics. 2016. Vol. 74. P. 31.

17. Harter J.W., Zhao Z.Y., Yan J. et al. A paritybreaking electronic nematic phase transition in the spin-orbit coupled metal Cd_2Re_2O_7 // Science. 2017. Vol. 356. № 6335. P. 295.

18. Taton T.A. Nanoscale Materials in Chemistry Edited by Kenneth J. NY: Wiley-Interscience, 2001. 292 p.
19. Djurabekova F., Backman M., Pakarinen O.H. et al. Amorphization of Ge nanocrystals embedded in amorphous silica under ion irradiation // Nuclear Instruments and Methods in Physics Research Section B: Beam Interactions with Materials and Atoms. 2009. Vol. 267. № 8. C. 1235.

20. Смирнов Л.С. Физические процессы в облученных полупроводниках. - Новосибирск: Наука, 1977. С. 21.

21. Shaw H.C., Liu D., Jacobs B.W. et al. 12th NASA Symposium on VLSI Design, Coeur d'Alene, Idaho, USA, Oct. 4-5, 2005.

22. Герасименко Н.Н., Смирнов Д.И., Медетов Н.А. и др. Влияние размерных эффектов на радиационную стойкость нанокристаллических материалов // Известия вузов. Электроника. 2013. № 6(104). С. 24-31.

23. Misra A., Demcowicz M.J. et al. The Radiation Damage Tolerance of Ultra-High Strength Nanolayered Composites // JOM, 2007. No 9. P. 62-65.

24. Romanov S.I., Smirnov L.S. Interaction of point-defects with $\mathrm{SiO}_{2}-\mathrm{Si}$ interface // Soviet physics semiconductors-USSR. 1976. Vol. 10. № 5. P. 519.

25. Емцев В.В., Машовец Т.В. Примеси и точечные дефекты в полупроводниках. - М.: Радио и связь, 1981. 248 с.

26. Djurabekova F., Backman M., Nordlund K. Atomistic modelling of the interface of $\mathrm{Si}$ nanocrystal structures in $\mathrm{a}-\mathrm{SiO}_{2}$ before and
(Fig.6b). Residual visibility in the non-irradiated region is caused by the fact that diffraction occurs in the surface silicon layer with a greater thickness than amorphizated layer. Study of fast electron diffraction was conducted at an accelerating voltage of $30 \mathrm{kV}$, a current of $9.7 \mathrm{nA}$, a slope of surface of $70^{\circ}$. Under these conditions the electrons are mostly reflected from the surface, and only a small part of them with high energy penetrates to a depth of about 150$200 \mathrm{~nm}$.

Thus, it is experimentally shown that the surface of the crater is amorphizated. This implies that the predominant mechanism in the formation of the walls of the cylinder is not the resputtering, but a plastic flow associated with the introduction of an excessive concentration of mobile radiation defects. It can be concluded that in the described experiment that is carried out in the framework of the study [50], the dependence of the process of formation of periodic structures during ion etching on the current density of the ion beam and the independence on time of etching have been registered. The obtained results are in contradiction with the classical views on the formation of topography during ion etching by resputtering of material, which makes necessary the discussion of alternative points of view on this process. An alternative mechanism that is associated with plastic flow [48] have been discussed in the world scientific literature recently. Also, it should be noted that a similar effect was observed for metals in a recent article [49], however, our team has discovered this effect a few years earlier [50].

According to modern concepts, in case of the irradiation of the monocrystalline substrate by an ion beam that is directed to the 
after ion irradiation // Nuclear Instruments and Methods in Physics Research B. 2008. Vol. 266. P. 2683.

27. Hoffmann S., Bauer J., Ronning C., et al. Axial p-n Junctions Realized in Silicon Nanowires by Ion Implantation // Nano Letters. 2009. Vol. 9. P. 1341 .

28. Kanungo P.D., Kogler R., Nguyen-Duc K. et al. Ex situ $n$ and p doping of vertical epitaxial short silicon nanowires by ion implantation // Nanotechnology. 2009. Vol. 20. P. 165706.

29. Borschel C., Niepelt R., Geburt S. et al. Alignment of Semiconductor Nanowires Using Ion Beams // Small. 2009. Vol. 5. P. 2576.

30. Pecora E.F., Irrera A., Boninelli S. et al. Nanoscale amorphization, bending and recrystallization in silicon nanowires // Applied Physics A. 2011. Vol. 102. P. 13.

31. Brousseau E.B., Dimov S.S. \& Pham D.T. Some recent advances in multi-material microand nano-manufacturing // The International Journal of Advanced Manufacturing Technology 47. 2009. P. 161-180. DOI: $10.1007 / \mathrm{s} 00170-$ 009-2214-5.

32. Inkson B.J., Mulvihill M. \& Möbus G. 3D determination of grain shape in a FeAl-based nanocomposite by 3D FIB tomography // Scripta Materialia 45. P 753-758. 2001. DOI: 10.1016/ S1359-6462(01)01090-9.

33. Lasagni $F$. et al. Three-dimensional characterization of 'as-cast' and solution-treated AlSi12(Sr) alloys by high-resolution FIB tomog- raphy // Acta Materialia 55. P 3875-3882. 2007. DOI: 10.1016/j.actamat.2007.03.004.

34. Mayer J., Giannuzzi L.A., Kamino T. \& Michael J. TEM Sample Preparation and FIBInduced Damage // MRS Bulletin 32. P. 400407. 2007. DOI: $10.1557 / \mathrm{mrs} 2007.63$.

35. Giannuzzi L.A. \& Stevie F.A. A review of focused ion beam milling techniques for TEM specimen preparation // Micron 30. P. 197-204. 1999. DOI: 10.1016/S0968-4328(99)00005-0.

36. Mayr G., Ashkenazy Y., Albe K. et al. Mechanisms of Radiation-Induced Viscous Flow: Role of Point Defects // Physics Review Letters. 2003. Vol. 90. No. 5. P. 055505.

37. Uchic M.D., Dimiduk D.M., Florando J.N. \& Nix W.D. Sample Dimensions Influence Strength and Crystal Plasticity // Science 305. P. 986-989. 2004. DOI: 10.1126/science.1098993.

38. Robinson M.T. \& Torrens I.M. Computer simulation of atomic-displacement cascades in solids in the binary-collision approximation // Physical Review B 9. 1974. P. 5008-5024.

39. Yi X. et al. Direct observation of size scaling and elastic interaction between nano-scale defects in collision cascades // Europhysics Letters 110. 36001. 2015.

40. Giannuzzi L.A. \& Stevie F.A. A review of focused ion beam milling techniques for TEM specimen preparation // Micron 30. P. 197-204. 1999. DOI: 10.1016/S0968-4328(99)00005-0.

41. Hofmann, F. et al. Lattice swelling and modulus change in a helium-implanted tungsten alloy: surface at some angle $\theta$ less than critical, the cascades of radiative offsets arise, leading to directional motion of significant flows of interstitial and vacancy defects near the surface accompanied by plastic flow of material [48]. The density of defects in these radiative cascades is high, which leads to complete amorphization of the surface layer.

\section{CONCLUSION}

The considered results show that the reduction in size of the elements of the structure down to the nanoscale can lead to dramatic changes in its mechanical properties, therefore we should pay attention to the results on nanostructure formation of record small sizes, as have been demonstrated recently by IBM (FinFet transistor structure with $7 \mathrm{~nm}$ node) [51].

Special attention to the condition of the structure of nanoscale objects should be given when considering the results of radiation effects on the nanoobjects. The sharp increase in radiation resistance in nanoobjects [8], which is reflected in a change in the functional properties of the devices, contradicts to the facts of reduction of the dose of amorphization of nano-objects [26]. These issues were discussed in [52], and also in the number of studies carried out in our laboratory $[7,54]$. It should be noted that the phase transition at a lower (in comparison with the single crystal) doses of irradiation is associated, in our opinion, with the accumulation of critical doses of defects, in particular of vacancy $\mathrm{V}-\mathrm{V}$ centres [53], which consists of the equilibrium concentration and non-equilibrium radiation component. In this case, the expected equilibrium concentration at a given temperature is increased [54]. In this case, it is expected that the equilibrium 
X-ray micro-diffraction, surface acoustic wave measurements, and multiscale modelling // Acta Materialia. 2015. Vol. 89. P. 352.

42. Shim S., Bei H., Miller M.K., Pharr G.M. \& George E.P. Effects of focused ion beam milling on the compressive behavior of directionally solidified micropillars and the nanoindentation response of an electropolished surface // Acta Materialia. 2009. Vol. 57. P. 503.

43. Kiener D., Motz C., Rester M., Jenko M. and Dehm G. FIB damage of $C$ and possible consequences for miniaturized mechanical tests // Materials Science and Engineering: A. 2007. Vol. 459. P. 262.

44. Giannuzzi L. A., Geurts R. and Ringnalda J. 2 $\mathrm{keV} \mathrm{Ga}+$ FIB Milling for Reducing Amorphous Damage in Silicon // Microscopy and Microanalysis. 2005. Vol. 11. P. 828.

45. Yu J., Liu J., Zhang J. \& Wu J. TEM investigation of FIB induced damages in preparation of metal material TEM specimens by FIB // Materials Letters. 2006. Vol. 60. P. 206.

46. Сборник тезисов конференции ConFab 2017, May 14-17, 2017. San Diego, CA. [URL]: http://theconfab.com/2017-conference/2017conference-proceedings.

47. Engineering techniques is damaging material, research reveals // Solid state technology blogs [URL]: http://electroiq.com/blog/2017/04/engineeringtechnique-is-damaging-materials-research-reveals.

48. Castro M., Gago R., Vazquez L. et al. Stressinduced solid flow drives surface nanopattern- ing of silicon by ion-beam irradiation // Physics Review B. 2012. Vol. 86. P. 214107.

49. Hofmann F., Tarleton E., Harder R.J. et al. 3D lattice distortions and defect structures in ion-implanted nanocrystals // Science Reports. 2017. Vol. 7. P. 45993.

50. Gerasimenko N.N., Chamov A.A., Medetov N.A. et al. Specific Features of Relief Formation on Silicon Etched by a Focused Ion Beam // Technical Physics Letters. 2010. Vol. 36. № 11. P. 991.

51. Antony S. Beyond silicon: IBM unveils world's first $7 \mathrm{~nm}$ chip [URL]: https://arstechnica. co.uk/gadgets/2015/07/ibm-unveils-industrysfirst-7nm-chip-moving-beyond-silicon.

52. Герасименко Н.Н., Смирнов Д.И., Запорожан О.А. Радиационная стойкость полупроводниковых наноструктур // В кн.: Физические и физико-химические основы ионной имплантации: Тезисы докладов V Bсероссийской конференции и школы молодых ученых и специалистов. - Н. Новгород. 2014. C. 32.

53. Gerasimenko N.N., Dvurechenskii A.V., Smirnov L.S. et al. Amorphisation of ion implanted crystals // Crystall Lattice Defects. 1971. Vol. 2. P. 125.

54. Герасименко Н.Н., Смирнов Д.И., Медетов Н.А. и др. Влияние размерных эффектов на радиационную стойкость нанокристаллических материалов // Известия вузов. Электроника. 2013. Вып. 6. № 104. С. 31. concentration at a given temperature is increased [54].

Under the proposed unified approach to the consideration of properties of nanoscale objects, taking into account the interaction of moving defects with the boundaries of nanosized objects and the influence of surfaces and interfaces, it is possible to develop a description of various physical phenomena such as amorphization and plastic flow of solid materials. The transition of the object through the size threshold leads to a sharp change in the structure and related properties. First of all, it concerns the state of ordering of atoms, which in extreme cases can be crystalline or amorphous. In our paper [50] it is shown that radiative processes can lead to so significant changes in the structure, that on the borders of etching the formations associated with the formation of areas with plastic flow can be observed. The same effect was discussed in detail at a recent ConFab conference [47], and in [49] it was considered in more detail, but the results practically coincide with results of previously published work [50].

The considered size effects of the change of mechanical properties and structure of nanoscale objects should be taken into account in the manufacture of samples, sample preparation, and in conducting research because they can contribute distortions in the observed result. Manifestations of quasi-liquid (amorphous) properties are possible both in production and in the study of samples. This affects not only the processing and inspection in the laboratory but also process control in situ.

This work was supported by grant of the Russian Science Foundation, project No. 15-19-10054. 